1 Assessment of the diversity and abundance of the total and active fungal population and

2 its correlation with humification during two-phase olive mill waste ("alperujo")

\title{
3 composting
}

4

5 Germán Tortosa ${ }^{\mathrm{a}}$, Fernando Torralbo ${ }^{\mathrm{b}}$, Paula Maza-Márquez ${ }^{\mathrm{c}, \mathrm{d}, 1}$, Elisabet Aranda ${ }^{\mathrm{c}, \mathrm{d}^{*}}$,

6 Concepción Calvo ${ }^{\mathrm{c}, \mathrm{d}}$, Carmen González-Murua ${ }^{\mathrm{b}}$ and Eulogio J. Bedmar ${ }^{\mathrm{a}}$

7

8 a Department of Soil Microbiology and Symbiotic Systems. Estación Experimental del

9 Zaidín (EEZ), Agencia Estatal CSIC, c/ Profesor Albareda, 1, 18008, Granada, Spain.

$10{ }^{b}$ Department of Plant Biology and Ecology, University of the Basque Country

11 (UPV/EHU), Barrio Sarriena, s/n, 48940, Leioa, Bizkaia, Spain.

12 ' Institute of Water Research, University of Granada, Edificio Fray Luis, c/ Ramón y

13 Cajal, 4, 18003, Granada, Spain.

14 department of Microbiology, Faculty of Pharmacy, University of Granada, Campus de 15 Cartuja, s/n, 18071, Granada, Spain.

16

17 *Corresponding author: Elisabet Aranda (earanda@ugr.es)

18 Phone: $(+34) 958241000$ (20379)

$19{ }^{1}$ Present address: Exobiology Branch, NASA Ames Research Center, Moffett Field, $20 \quad$ CA, USA 


\section{Abstract:}

22 Metagenomic and transcriptomic techniques applied to composting could

23 increase our understanding of the overall microbial ecology and could help us to

24 optimize operational conditions which are directly related with economic interest. In

25 this study, the fungal diversity and abundance of two-phase olive mill waste

26 ("alperujo") composting was studied using Illumina MiSeq sequencing and quantitative

27 PCR, respectively. The results showed an increase of the fungal diversity during the

28 process, being Ascomycota the predominant phyla. Penicillium was the main genera

29 identified at mesophilic and maturation phases, and Debaryomyces and Sarocladium at

30 thermophilic phase, respectively. The fungal abundance was increased during

31 composting, which confirm their important role during thermophilic and maturation

32 phases. Some Basidiomycota showed an increased during the process, which showed a

33 positive correlation with the humification parameters. According to that, the genus

34 Cystofilobasidium could be used as a potential fungal biomarker to assess AL compost

35 maturation.

36

37

38

39

$40 \quad$ Keywords:

41 Fungal community; Illumina MiSeq; Two-phase olive mill waste, qPCR, 


\section{Introduction}

The agrofood and food processing industries generate an important amount of

44 wastewater, by-products, sewage sludge and organic wastes loads, which can be reused

45 as organic amendments after biological treatments (Morales et al., 2016). One example

46 is the olive oil industry, which yearly generates millions of tons of "alperujo or

47 alpeorujo" (AL) in the Mediterranean basin, an acidic and highly contaminant sludge,

48 rich in phenolic compounds (Alburquerque et al., 2004). Composting has been shown as

49 an efficient and low-cost technology for AL treatment and the composts produced are

50 often used as organic amendments and fertilisers in agricultural soils (Muktadirul Bari

51 Chowdhury, et al., 2013; Tortosa et al., 2012;Tortosa et al., 2014).

52 Composting is the biological process in which, the organic matter is aerobically

53 degraded by the metabolic activity of the microbial population dwelling in the raw

54 materials (de Bertoldi et al., 1983; Ryckeboer et al., 2003). In this controlled process, an

55 extensive microbial succession occurs, mainly bacteria and fungi (López-González et

56 al., 2015a, b). It is commonly accepted that bacterial population activity is more

57 intensive during mesophilic and thermophilic phases compared to activities from fungi

58 or actinomycetes, which are more active during maturation. This is due to the fast

59 metabolism of bacteria, being more competitive than fungal populations, and their

60 higher surface/volume ratio, diversity and generation times, which allow them to better

61 adapt to the rapid substrate changes and conditions occurring during composting

62 (Ryckeboer et al., 2003). It is well known that fungal populations play a pivotal role in

63 organic matter degradation and carbon cycling, especially during maturation phase,

64 when the humification occurs (de Bertoldi et al., 1983). Different studies have also 
65 shown the capability of fungi to remove the phenols presents in AL and humify this by-

66 product, thanks to the presence of an enzymatic toolbox to remove lignocellulosic

67 substrates (Reina et al., 2017; Sampedro et al., 2004).

68 Recently, high-throughput sequencing technologies like Illumina MiSeq/HiSeq

69 or quantitative polymerase chain reaction (qPCR) have been applied to composting,

70 which are increasing our understanding of the overall microbial ecology of that process

71 (Antunes et al., 2016). Bacteria and fungi are the two most abundant groups of compost

72 microorganisms. However, the vast majority of the available studies in composting are

73 focused on bacteria, since fungal databases display limitations related to the number of

74 sequenced, well annotated fungal genomes and the absence of a universally accepted

75 DNA barcode (Gopal et al., 2017). Nevertheless, new data about fungal diversity and

76 abundance of different composting configurations, materials or bulking agents

77 (lignocellulosic, food and garden wastes, press mud, cattle manure with construction

78 and demolition wastes, cow manure, pumice or sewage sludge) have been provided

79 which could help to optimize operational conditions (de Gannes et al., 2013; Galitskaya

80 et al., 2017; Holman et al., 2016; Langarica-Fuentes et al. 2014; Neher et al., 2013;

81 Oliveira et al., 2016; Tian et al., 2017; Wang et al., 2018 a,b; Yu et al., 2015).

82 Only one report using high-throughput sequencing applied to olive mill waste

83 composting has been published. In Tortosa et al. (2017), we evaluated how bacterial

84 population was affected by the process and we found several genera that could be use as

85 potential biomarkers for maturation. On the other hand, no studies have been currently

86 published about fungal abundance using qPCR from the genomic DNA and the

87 retrotranscripted cDNA. Taking all these facts into account, the aims of this work were 
to study i) how the diversity and the abundance of the total and metabolically active

89 fungal population evolved during AL composting using Illumina MiSeq sequencing and

90 qPCR technologies, and ii) their correlations among the physicochemical characteristics

91 of the process, with emphasis on finding fungal biomarkers of humification of the $\mathrm{AL}$

92 compost.

93

94 2. Materials and methods

$95 \quad$ 2.1. Composting performance and compost sampling

96 The AL composting procedure, physicochemical and bacterial evolution and

97 composts characterization used in this study were previously described by Tortosa et al,

98 (2012 and 2017). Briefly, the AL was mixed with sheep manure in equal proportions of

99 fresh weight $(1: 1)$ and then, two trapezoidal piles of $10 \mathrm{t}$ each were done as biological

100 replicates (M1 and M2). These piles were managed under the open system of windrow

101 piles using a backhoe loader. A total of seven mechanical turnings were made according

102 to the temperature and the biooxidative phase evolution, respectively. The moisture was

103 kept above $40 \%$, using an aspersion irrigation system and the composting process

104 lasted 22 weeks.

105 Mesophilic ( $1^{\text {st }}$ week $)$, thermophilic $\left(7^{\text {th }}\right.$ week $)$ and maturation phases $\left(22^{\text {nd }}\right.$

106 week) were sampled. For each phase, a composite sample of $1 \mathrm{~kg}$ were made by mixing

107 25-30 subsamples, which were randomly taken from several localizations of M1 and

108 M2 piles (different heights, lengths and depths, respectively). Composite samples were

109 transported into the lab within 4 hours after sampling using a portable fridge and were

110 kept at $-80{ }^{\circ} \mathrm{C}$ until genomic analysis. Three replicates per composting phase were 
111 performed and individually extracted and analyzed. The nomenclature of these samples

112 was: Meso1-3 (Meso1, Meso2 and Meso3); Thermo1-3 (Thermo1, Thermo2 and

113 Thermo3); Matu1-3 (Matu1, Matu2 and Matu3) for mesophilic, thermophilic and

114 maturation phases, respectively.

115

116 2.2. Genomic DNA, RNA extraction and cDNA retrotranscription

117 Total genomic DNA extraction was carried out using a protocol previously used

118 (Tortosa et al., 2017). Briefly, frozen compost $\left(-80^{\circ} \mathrm{C}\right)$ samples $( \pm 5 \mathrm{~g})$ were added into

119 a sterile porcelain mortar, homogenized by adding liquid nitrogen and ground using a

120 sterile pestle as it was recommended by Neher et al., (2013). After that, $250 \mathrm{mg}$ of

121 compost samples were weighed and extracted using the commercial PowerSoil@ DNA

122 isolation kit (MO BIO, Catalog No. 12888-100) after mechanical shaking using a

123 Mikro-Dismembrator S (Sartorius Stedim Biotech) for $30 \mathrm{~s}$ at $1600 \mathrm{rpm}$. Genomic

124 DNAs were resuspended in molecular biology grade water, electrophoresed in $1 \%$

125 agarose gel (40 min at $80 \mathrm{mV}$ ), and visualized using GelRed ${ }^{\circledR}$ Nucleic Acid Gel Stain

126 (Biotium, Catalog No. \#41003-1). Finally, genomic DNAs were quantified using a

127 Qubit ${ }^{\mathrm{TM}} 4$ Fluorometer (Invitrogen, Catalog No. Q33226) and were kept at $-20{ }^{\circ} \mathrm{C}$ until

128 genomic analysis.

129 RNA extraction was performed using frozen compost samples $\left(-80^{\circ} \mathrm{C}\right)$ and

130 homogenized and extracted as described above. The compost weights were previously

131 optimized according to their humic acids concentration: $1.5,0.5$ and $0.2 \mathrm{~g}$ (fresh weight)

132 for mesophilic, thermophilic and maturation samples, respectively. Commercial RNA

133 PowerSoil ${ }^{\circledR}$ Total RNA Isolation kit (MO BIO, Catalog No. 12866-25) was used 
134 according to manufacter's instructions. The RNAs obtained were quantified using a

135 Nanodrop 1000 Spectrophotometer (Thermo Scientific) at $260 \mathrm{~nm}$ and were treated with

136 DNase I (RNase free) (Abion, Life technologies, Catalog No. AM2222) to remove co-

137 extracted DNA. The treatment was done according to manufacter's instructions and its

138 efficiency was checked by $18 \mathrm{~S}$ rRNA gene qPCR amplification as is mentioned below.

139 After that, a reverse transcription was done using the PrimeScript TM RT

140 reagent Kit (Takara Bio INC, Catalog No. \#RR037A) following the manufacter's

141 instructions. Equal RNA ( $100 \mathrm{ng})$ quantity from for all compost samples was used

142 using the Random 6 mers option. Finally, cDNAs obtained were quantified using a

143 Qubit ${ }^{\mathrm{TM}} 4$ Fluorometer (Invitrogen, Catalog No. Q33226) and were kept at $-20^{\circ} \mathrm{C}$ until 144 analysis.

\subsection{Illumina MiSeq amplification, taxonomic assignment and diversity indices}

147 The internal transcribed spacer (ITS) region was amplified by Illumina MiSeq

148 sequencing technology, at the facilities of Life Sequencing S.L. (Valencia, Spain). The

149 ITS1-F-KYO2 (5'-CTHGGTCATTTAGAGGAASTAA-3') and ITS2-KYO1 (5'-

150 CTRYGTTCTTCATCGDT-3') primers and PCR conditions used were previously

151 described by Toju et al. (2012). Before amplification, genomic DNA samples were

152 purified using PowerClean ${ }^{\circledR}$ DNA Clean-Up Kit (MO BIO, Catalog No. 12877-50) and

153 tested for PCR inhibition. A total of 18 amplicons were obtained and the raw sequences

154 were cured for quality (quality score of 20) and the Illumina primer's barcodes were

155 removed using PEARL software V.0.9.1 (available in

156 http://www.exelixis-lab.org/web/software/pear) and CUTADAPT V.1.8.1. (Available in 
$157 \mathrm{http}: / /$ cutadapt.readthedocs.io/en/stable/), respectively. Sequences shorter than 200

158 nucleotides or unresolved nucleotides were eliminated, as well as chimeras.

159 For each amplicon, the taxonomical assignation and the relative abundances

160 were done as was described in Cole et al. (2014), using the Ribosomal Data Project

161 website. The RDP classifier tool according to UNITE Fungal ITS gene option at 80\%

162 confidence Cut-off (RDP, release 11.5, http://pyro.cme.msu.edu) was employed, and the

163 raw sequences were aligned and clustered into operational taxonomic units (OTUs)

164 using the Infernal Alignment and the Complete Linkage Clustering RDP tool

165 (unsupervised method), respectively. In addition, Good's coverage index, Shannon-

166 Wiener (H') and Chao-1 diversity indices were calculated using the available RDP web

167 tools.

169 2.4. Quantitative PCR (qPCR)

170 The number of copies of 18S rRNA gene from genomic DNA and cDNA was

171 quantified by qPCR using FungiQuant quantitative real-time PCR assay (FungiQuant-F

172 5'-GSWCTATCCCCAKCACGA-3' and FungiQuant-R 5'-

173 GGRAAACTCACCAGGTCCAG-3') (Maza-Márquez et al., 2018). The qPCR was

174 performed in a Step One Plus ${ }^{\mathrm{TM}}$ Real-Time PCR system (Agilent Technologies) using

175 an Mx3000P System. The qPCR reactions were performed in triplicate using the iTaq

176 Universal SYBR Green Supermix (Sigma Aldrich, Catalog No. \#172-5125) with a final

177 reaction volume of $25 \mu$. The following conditions were used for PCR amplification:

$17895^{\circ} \mathrm{C}$ for $3 \mathrm{~min}, 40$ cycles consisting of $94{ }^{\circ} \mathrm{C}$ for $30 \mathrm{~s}, 62{ }^{\circ} \mathrm{C}$ for $30 \mathrm{~s}$ and $72^{\circ} \mathrm{C}$ for $45 \mathrm{~s}$, 179 and $72{ }^{\circ} \mathrm{C}$ for $7 \mathrm{~min}$. 
181 serial tenfold dilution $\left(10^{-1}-10^{-8}\right)$ from a linearised plasmid (pGEM-T Easy vector,

182 Promega, Catalog No. A1360) in which the target gene was inserted. Amplicons of $18 \mathrm{~S}$

183 rDNA were generated from the culture of Candida albicans strain ATCC 10231 (Maza-

184 Márquez et al., 2018). The PCR products were cloned using the TOPO ${ }^{2}$ TA cloning ${ }^{\circledR}$

185 system (Invitrogen, Catalog No.K457501), following the manufacturer's instructions.

186 The calibration curves showed a correlation coefficient $\mathrm{r}^{2}>0.99$ and the efficiency of

187 PCR amplification was between $90-100 \%$ in all the assays. Melting curve was

188 constructed using increasing temperature from $60^{\circ} \mathrm{C}$ to $95^{\circ} \mathrm{C}$. Verifications of each

189 primers size and single band after qPCR were performed by electrophoresis in agarose.

190 Results were expressed as the copy numbers of $18 \mathrm{~S}$ rRNA gene from DNA or cDNA

191 per compost dry weight of (CDW) in grams (g).

\section{$193 \quad$ 2.5. Statistical analysis}

194 The mean and the absolute error of the abundance of relative sequences were

195 estimated for Mesophilic, Thermophilic and Maturation phases, respectively. Also, the

196 Statistical Analysis of Taxonomical and Functional Profiles (STAMP) open-source

197 software v2.0.9 release (Parks et al., 2014) was used to calculate the one-way ANOVA

198 with Tukey-Kramer post-hoc test at $p<0.05$, applying Storey's FDR for multiple

199 correction and eta-squared for sample size correction tests, respectively. These

200 statistical tests were done assuming normal distribution and homoscedasticity of the raw

201 data. According to user's guide recommendations, STAMP option of Principal

202 Component Analysis (PCA) and the unweighted pair-group method with arithmetic 
203 average (UPGMA) plotted as a dendrogram were used to estimate the phyla distribution 204 among piles and composting phases respectively at 0.75 of threshold.

Finally, Pearson correlation coefficients were calculated using GNU-PSPP open206 source software v0.9.0 (available in https://www.gnu.org/software/pspp/) to estimate the 207 relationships between physico-chemical characteristics of AL composts, previously 208 published in Tortosa et al. (2017) and fungal community at the order level.

\section{$210 \quad$ 2.6. Accession numbers}

211 Illumina sequences are available at the EMBL-EBI European Nucleotide

212 Archive Database (http://www.ebi.ac.uk/ena) under the accession numbers

213 ERS3048724-ERS3048741.

215 3. Results and discussion

216 3.1. Sequencing analysis and diversity indices

217 Clone libraries could provide an important estimation on microbial diversity 218 during composting processes (López-González et al., 2015 a, 2015b). However, high-

219 throughput sequencing technologies applied to composting are providing relevant

220 information on the microbiome of these processes. In this study, Illumina MiSeq was-

221 used to analyze the mycobiome in a real composting process during mesophilic,

222 thermophilic and maturation phases, respectively. The number of sequences obtained

223 before curing ranged in 73263-81375 for the composting libraries, being the total

224 unclassified sequences less than $0.5 \%$ of the total sequences (Table 1 ). These values

225 agree with those described by Gu et al. (2017) and Wang et al. (2018a) for chicken 
226 manure and cow manure composting, respectively. According to the taxonomical

227 classification (Table 1), the identification percentage of the sequences at each

228 composting phase was relevant (>97\%), descending to $80 \%$ at order level in the

229 thermophilic phase.

230 Diversity indices like OTUs richness (R), the Good's coverage and the Shannon

231 (H') and Chao-1 indices applied to high-throughput analyses have been widely used in

232 order to assess the microbial evolution along the process. In the present study, OTUs

233 Richness ranged between 1426-2320 and Good's coverage index showed values

234 between $90.0-94.9 \%$ (Table 2). According to these values, it can be concluded that the

235 sequences obtained were representative of the fungal community in the compost

236 samples. The diversity expressed as Shannon-Wiener $H^{\prime}$ index, increased during the

237 process, being at the thermophilic phase higher $\left(H^{\prime}: 4.29\right)$ compared to the mesophilic

$238\left(H^{\prime}: 2.77\right)$ or maturation $\left(H^{\prime}: 3.14\right)$ phases. In addition, the Chao-1 index showed the

239 highest value at the thermophilic phase (Chao-1: 3844) in agreement with the H' value.

240 Results obtained by López-González et al. (2015b) found less fungal diversity

241 associated to cooling or maturation stages. Also, Tian et al. (2017) showed an increased

242 in Shannon and Simpson indices during composting of Chinese medicinal herbal

243 residues. Meanwhile, Huhe et al. (2017) noted the opposite behaviour during

244 composting cattle farm waste, an inverse parabolic diversity evolution within

245 temperature and time. Despite this apparent discrepancy, it might be inferred that fungal

246 diversity could be directly related to the temperature evolution during the process and

247 the native fungal population of raw materials used for composting.

248 


\subsection{Fungal diversity}

In general terms, Ascomycota was the predominant phylum along the process,

251 representing more than $90 \%$ of the total sequences identified at mesophilic,

252 thermophilic and maturation phases (Fig. 1). Basidiomycota was also relevant during

253 thermophilic and maturation phases, accounting for $5.48 \pm 1.19$ and $9.73 \pm 2.03 \%$ of

254 the total sequences identified, respectively. Ascomycota is the largest phylum of fungi

255 and they occur in numerous terrestrial and aquatic ecosystems (Schoch et al., 2009).

256 This phylum is commonly found during composting processes and has been previously

257 described as the predominant phylum in olive mill waste composting (Ntougias et al.,

258 2013) and in other organic waste composting like Chinese medicinal herbal residues

259 (Tian et al., 2017) or cow manure (Wang et al., 2018a).

260 Figure 2 represents the evolution of the most relevant order indentified during

261 the process. Chaetothyriales, Diaporthales, Hypocreales and Saccharomycetales

262 (Ascomycota) (Fig. 2A); Agaricales and Atheliales (Basidiomycota) (Fig. 2B); and

263 Mucorales (Zycomycota) (Fig. 2C), significantly increased during thermophilic phase,

264 meanwhile Capnodiales and Eurotiales, belonging to Ascomycota decreased (Fig. 2A).

265 On the other hand, the basidiomycetous Cystofilobasidiales, Sporidiobolales and

266 Tremellales increased at the end of the process, especially during maturation (Fig. 2B).

267 According to genera classification (Table 3), Penicillium, Davidiella and

268 Debaryomyces were the principal genera identified at mesophilic phase, accounting for

$26993.68 \pm 0.28,2.63 \pm 0.23$ and $1.36 \pm 0.30 \%$ of the total sequences identified,

270 respectively. In the thermophilic phase, the most predominant genera were Sarocladium

271 and Debaryomyces, which statistically increased $(p>0.05)$ at $33.43 \pm 1.42$ and $24.55 \pm$ 
$272 \quad 1.40 \%$ of the sequences.

273 Our results are in accordance with Cho et al. (2009), who also detected the

274 presence of the xerotolerant yeast Debaryomyces hanseii in pig manure and mushroom

275 cultural waste composting at the thermophilic composting phase. Sarocladium is known

276 as a plant pathogen, especially responsible for the sheath rot in rice. However, it is also

277 used as fungal pathogen control due to its antagonistic activity against other fungi by

278 producing cerulenin, a secondary metabolite which inhibits fatty acid and steroid

279 metabolism (Araújo et al., 2017). It is probable that Sarocladium was present in the

280 bedding of the sheep manure used for composting, but fortunately, it was not present in

281 mature composts indicating the sanitization capability of the composting process. Other

282 minority genera increased at this phase such as Athelia $(4.09 \pm 1.09 \%)$, Togninia $(2.17$

$283 \pm 0.89 \%)$, Coprinellus $(1.16 \pm 0.09 \%)$ and Mucor $(1.13 \pm 0.12 \%)$.

284 Penicillium, however, drastically decreased at this phase $(2.69 \pm 0.23 \%)$,

285 probably displaced by thermotolerant species. In addition, an important percentage of

286 unclassified sequences were found (22.66 $\pm 2.86 \%)$. Mucor and Coprinellus are well-

287 known thermotolerant species and the last one also involved in lignocellulose

288 degradation (Singh et al., 2009). At maturation phase, Penicillium shown absolute

289 predominance, with close to $80 \%$ of the sequences identified, together with

290 Debaryomyces, Cystofilobasidium and Rhodosporidium, which represented 7.76 \pm 1.11 ,

$2915.31 \pm 1.96$ and $3.61 \pm 0.18 \%$ of the sequences identified, respectively. Penicillium is a

292 well known inhabit fungi of composting processes since several representatives of this

293 genus can resist adverse conditions, including high temperatures and high pollutant

294 concentrations. This fungus is also typically isolated by using culture-dependent 
295 technologies in lignocellulose-based composting (López-González et al., 2015b) and it

296 is able to transform lignocellulosic substrates thanks to the secretion of hydrolytic

297 enzymes. This fungus is widespread in olive mill wastes (Ntougias et al., 2013) and

298 composts from different origin (Ryckeboer at al., 2003), such as composts from manure

299 and wood wastes (Neher at al., 2013). Indeed, this mesophilic fungus seems to be a

300 promising tool to enhance composting process (Wang et al., 2011).

301

302

3.3. Fungal abundance (qPCR)

303

An increase in the number of copies of 18S rRNA gene from genomic DNA was

304 found during the process, which it was $2.74 \times 10^{5} \pm 4.49 \times 10^{4}, 4.90 \times 10^{5} \pm 8.12 \times 10^{4}$

305 and $4.97 \times 10^{5} \pm 1.53 \times 10^{5} \mathrm{CDW}\left(\mathrm{g}^{-1}\right)$ for mesophilic, thermophilic and maturation

306 phases, respectively (Fig. 3). This increase was statistically relevant $(p<0.05)$ from

307 mesophilic to thermophilic phases, but not between thermophilic and maturation. For

308 cDNA, an increase in the number of $18 \mathrm{~S}$ rRNA copies was also found during the

309 process, showing $5.90 \times 10^{4} \pm 4.96 \times 10^{3}, 1.19 \times 10^{5} \pm 9.30 \times 10^{3}$ and $2.29 \times 10^{5} \pm 8.30 \times$

$31010^{3} \mathrm{CDW}\left(\mathrm{g}^{-1}\right)$ for mesophilic, thermophilic and maturation phases, respectively.

311 The amplification and quantification of the number of 18S rRNA gene presents

312 in genomic DNA and retrotranscript RNA (cDNA) by qPCR could represent a useful

313 tool to estimate the abundance of total and metabolically active fungal population,

314 respectively (Benítez et al., 2018). Until now, few studies have been published using

315 this technology applied to composting. Galitskaya et al. (2017) showed an increase in

316 the number of $18 \mathrm{~S}$ rRNA copies amplified from genomic DNA (total fungal population)

317 during the cooling phase in municipal solid waste composting. On the other hand, Tian 
318 et al. (2017) found a slight decrease in the total fungal abundance during the Chinese

319 medicinal herbal composting. In the present study, we found an increase in the

320 abundance of fungal population during the process, especially the metabolically active

321 population (cDNA) during maturation. It is generally accepted that the fungal

322 community is more active during cooling and maturation phases than during the

323 mesophilic or thermophilic phases (Ryckeboer et al., 2003). Specific environmental

324 conditions of temperature, $\mathrm{pH}$ or moisture during mesophilic or cooling phases can

325 favour fungal proliferation (de Bertoldi et al., 1983). Moreover, it is assumed that fungal

326 enzymatic activities like cellulolityc and ligninolytic could be increased along the

327 process when temperature decreases (de Bertoldi et al., 1983).

328

\subsection{Statistical analysis: Heatmaps, PCA and Pearson correlations}

Reproducibility in metagenomic and transcriptomic studies is an important

331 factor to take into account. Understanding microbial succession could help to optimize

332 operational conditions which are directly related with economic interest. In this study

333 the heatmap and the dendrogram of the identified sequences at order level (Fig. 4)

334 revealed that the amplicons were grouped properly into three differential clusters

335 according to each composting phases (mesophilic, thermophilic and maturation),

336 showing that the amplification and sequencing were satisfactory for reproducibility and

337 repeatability. The principal component analysis (PCA) plot explained more than $98 \%$

338 of the total variances of the sequences identified at order level (PC1) and also, DNA

339 libraries belonging to each composting phase were similarly grouped (Fig. 4). As it was

340 noted in the dendrogram plot, the PCA showed that mesophilic and maturation 
341 amplicons were closed to each other compared to thermophilic counterparts that meant

342 that both composting phases showed similarities in the fungal diversity detected. These

343 data confirmed that the temperature is preferentially the main factor which affects the

344 fungal diversity and abundance during composting of lignocellulosic wastes like AL

345 (Toumela et al., 2000).

346 The Pearson correlation matrix showed that most of the sequences identified at 347 order level were significantly correlated $(r>0.7)$ with diversity indices (Shanon-

348 Wiener, H'; Chao-1 and Good) and also, with temperature evolution and cellulose 349 content during the process (Table 4). This behaviour was especially notable for orders

350 belonging to Ascomycota, being Capnodiales the order with more correlations with

351 Pearson coefficients (bigger that 0.7 within all parameters). On the other hand,

352 Basidiomycota preferentially showed significative correlations $(r>0.7)$ with parameters

353 related with the organic matter degradation and the humic substances formation. This

354 correlation was strongly notable during maturation, when Cysofilobasidiales,

355 Tremellales and Sporidiobolales were relatively more abundant. These orders showed a

356 negative correlations with organic matter (OM), hemicellulose, total organic carbon

357 (TOC), fat and water-soluble carbohydrates (WSCH) content, which were reduced

358 during the process. Meanwhile, humification degree (HD), the percentage of humic

359 acids $\left(\mathrm{P}_{\mathrm{AH}}\right)$ and germination index $(\mathrm{GI})$ were increased at the same time that

360 Cysofilobasidiales, Tremellales and Sporidiobolales relative abundance, showing

361 significative linear regressions correlation $\left(\mathrm{R}^{2}>0.85\right)$ (data not shown). Belonging to

362 Basidiomycota, the genera Cystofilobasidium is frequently found in composts from

363 different origin (Ryckeboer at al., 2003) like urban solid waste and sewage sludge 
364 composting (de Bertoldi et al., 1983), and agricultural wastes composting (Yu et al., 3652015 ) showing an important cellulolytic and ligninolytic activities (Goud et al., 2001).

366 The organic matter of AL composts is characterized by its important lignocellulosic 367 fraction (Alburquerque et al., 2009). It is well known that an important organic matter 368 degradation linked to humic substances formation happened (Tortosa et al., 2012), being 369 an ideal environment for Cystofilobasidium growth and propagation. Despite that more 370 research is needed to confirm it, Cystofilobasidium could be considered as a fungal 371 biomarker to asses AL compost maturation.

\section{Conclusions} The fungal diversity was increased during AL composting, being Ascomycota

375 the predominant phyla. Penicillium was the principal genera identified during the 376 process, especially at mesophilic and maturation phases, and thermotolerant species

377 such as Debaryomyces and Sarocladium dominated the thermophilic phase. The

378 abundance of the total and metabolically active fungal populations assessed by qPCR

379 was increased at the end of the process, which confirm the key role of fungi during

380 thermophilic and maturation phases. Some Basidiomycota were increased at the end and

381 positively correlated with humification parameters during composting, being

382 Cystofilobasidium a potential fungal biomarker to assess AL compost maturation.

\section{$384 \quad$ Conflict of Interest}

385 The authors declare that they have no conflict of interest. 
This work was supported by the ERDF-cofinanced projects from Junta de

389 Andalucía (Spain) [P12-AGR-1968], the Spanish MINECO [AGL2015-64582-CO3-02]

390 and MINECO-CSIC RECUPERA 2020 [20134R070]. G. Tortosa thanks to the farmer

391 J. González Almendros for his financial and technical assistance during AL composting

392 and also, to A. J. Fernández-González, A. Vicente-Lasa, M. Fernández-López and P. J.

393 Villadas for their helpful discussions. Support by Basque Country Government [IT-583

394 932-16] and the Spanish Red Sirena [AGL2015-68881-REDT] are also acknowledged.

395 E. Aranda thanks to MINECO-ERDF to support her Ramón y Cajal project [RYC-2013-

396 12481]. Finally, D. Francis Lewis is also acknowledged for the improvement of the

397 written English.

$399 \quad$ References

400 1. Alburquerque, J.A., Gonzálvez, J., García, D., Cegarra, J. 2004. Agrochemical

401 characterisation of "alperujo", a solid by-product of the two-phase

402 centrifugation method for olive oil extraction. Bioresour. Technol. 91, 195-200.

403 https://doi.org/10.1016/S0960-8524(03)00177-9.

404 2. Alburquerque, J.A., Gonzálvez, J., Tortosa, G., Baddi, G.A., Cegarra, J. 2009.

405 Evaluation of "alperujo" composting based on organic matter degradation,

406 humification and compost quality. Biodegradation. 20, 257-270. https://doi.org/

$407 \quad \underline{10.1007 / \mathrm{s} 10532-008-9218-\mathrm{y} .}$

408 3. Antunes, L., Martins, L., Pereira, R., Thomas, A., Barbosa, D., Lemos, L., Silva,

409 G., Moura, L., Epamino, G., Digiampietri, L., Lombardi, K., Ramos, P., 
Quaggio, R., de Oliveira, J., Pascon, R., Cruz, J., da Silva, A., Setubal, J. 2016.

Microbial community structure and dynamics in thermophilic composting viewed through metagenomics and metatranscriptomics. Sci. Rep. 38915. http:// dx.doi.org/10.1038/srep38915.

4. Araújo, R., Lemes da Silva, V., Carvalho, M.V., Corsi de Filippi, M.C., Sitarama, A., 2017. Characterization of Sarocladium oryzae and its reduction potential of rice leaf blast. Pesq. Agropec. Trop. 47, 1, 41-52. http://dx.doi.org/10.1590/s1678-3921.pab2019.v54.00295

5. Benítez, E., Paredes, D., Rodríguez, E., Aldana, D., González, M., Nogales, R., Campos, M., Moreno, B. 2018. Bottom-up effects on herbivore-induced plant defences: a case study based on compositional patterns of rhizosphere microbial communities. Sci. Report, 7: 6251. http://dx.doi.org/10.1038/s41598-017-06714$\underline{x}$.

6. Cho, K., Kwon, E., Kim, S., Kambiranda, D., Math, R., Lee, Y., Kim, J., Yun, H., Kim, H. 2009. Fungal diversity in composting process of pig manure and mushroom cultural waste based on partial sequence of large subunit rRNA. J Microbiol. Biotechnol. 19 (8), 743-748. http://dx.doi.org/10.4014/jmb.0807.455.

7. Cole, J.R., Wang, Q., Fish, J.A., Chai, B., McGarrell, D.M., Sun, Y., Brown, C.T., Porras-Alfaro, A., Kuske, C.R., Tiedje, J.M. 2014. Ribosomal Database Project: Data and tools for high throughput rRNA analysis. Nucleic Acids Res. 42, D633-42. http://dx.doi.org/10.1093/nar/gkt1244. 
8. de Bertoldi, M., Vallini, G., Pera, A. 1983. The biology of composting: a review. Waste Manage. Res. 1, 157-176. https://doi.org/10.1016/0734-242X(83)900551.

9. de Gannes, V., Eudoxie, G., Hickey, W.J. 2013. Insights into fungal communities incomposts revealed by 454-pyrosequencing: implications for human health and safety. Front. Microbiol. 4, 164. https://doi.org/10.3389/fmicb.2013.00164.

10. Galitskaya, P., Biktasheva, L., Saveliev, A., Grigoryeva, T., Boulygina, E., Selivanovskaya, S. 2017. Fungal and bacterial successions in the process of co-composting of organic wastes as revealed by 454 pyrosequencing. PLoS One. 12, 10, :e0186051. http://dx.doi.org/10.1371/journal.pone.0186051.

11. Gopal, M., Bhute, S.S., Gupta, A., Prabhu, S.R., Thomas, G.V., Whitman, W.B., Jangid, K. 2017. Changes in structure and function of bacterial communities during coconut leaf vermicomposting. Antonie van Leeuwenhoek, 110:1339-1355. http://dx.doi.org/10.1007/s10482-017-0894-7

12. Goud, J.V.S., Bindu, N.H., Samatha, B., Prasad, M.R., Charya, M.S.

2011. Lignolytic enzyme activities of wood decaying fungi from Andhra

Pradesh. J. Ind. Acad. Wood Sci. 8, 1, 26-31. https://doi.org/10.1007/s13196-

$\underline{011-0019-2}$.

451

13. Gu, W., Lu, Y., Tan, Z., Xu, P., Xie, K., Li, X., Sun, L., 2017. Fungi diversity from different depths and times in chicken manure waste static aerobic composting. Bioresour. Technol. 239, 447-453. 
14. Holman, D., Hao, X., Topp, E., Yang, H., Alexander, T. 2016. Effect of co-composting cattle manure with construction and demolition waste on the archaeal, bacterial, and fungal microbiota, and on antimicrobial resistance determinants. PLoS One. 11, 6, e0157539. http://dx.doi.org/10.1371/journal.pone.0157539.

15. Huhe, Jiang, C., Wu, Y., Cheng, Y., 2017. Bacterial and fungal communities and contribution of physicochemical factors during cattle farm waste composting. MicrobiologyOpen. 6, http://dx.doi.org/10.1002/mbo3.518.

16. Langarica-Fuentes, A., Zafar, U., Heyworth, A., Brown, T., Fox, G.,

Robson, G. 2014. Fungal succession in an in-vessel composting system characterized using 454 pyrosequencing. FEMS Microbiol. Ecol. 88, 2, 296-308. http://dx.doi.org/10.1111/1574-6941.12293.

17. López-González, J., Suárez-Estrella, F., Vargas-García, M., López, M.,

18. López-González, J., Vargas-García, M., López, M., Suárez-Estrella, F., Jurado, M., Moreno, J. 2015a. Dynamics of bacterial microbiota during lignocellulosic waste composting: Studies upon its structure, functionality and biodiversity. Bioresour. Technol. 175, 406-416. http://dx.doi.org/10.1016/j.biortech.2014.10.123. 
populations in a full-scale membrane bioreactor (MBR) treating urban wastewater by using quantitative PCR (qPCR). J. Environ. Manage. 1, 223, 1-8. https://doi.org/10.1016/j.jenvman.2018.05.093.

20. Morales, A., Bustamante, M., Marhuenda-Egea, F., Moral, R., Ros, M., Pascual, J. 2016. Agri-food sludge management using different co-composting strategies: Study of the added value of the composts obtained. J. Clean. Prod. 121, 186-197. https://doi.org/10.1016/j.jclepro.2016.02.012.

21. Muktadirul Bari Chowdhury, A.K.M., Akratos, C.S., Vayenas, D.V., Pavlou, S. 2013. Olive mill waste composting: A review. Int. Biodeterior. Biodegrad. 85, 108-119. https://doi.org/10.1016/j.ibiod.2013.06.019

22. Neher, D.A., Weicht, T.R., Bates, S.T., Leff, J.W., Fierer, N. 2013.

Changes in bacterial and fungal communities across compost recipes, preparation methods and composting times. PLoS One 8 (11), e79512. http://dx.doi.org/10.1371/journal.pone.0079512.

23. Ntougias, S., Bourtzis, K., Tsiamis, G. 2013. The microbiology of olive mill wastes. BioMed Res. Int. 2013, 784591. http://dx.doi.org/10.1155/2013/784591.

24. Oliveira, T.B., Lopes, V.C., Barbosa, F.N., Ferro, M., Meirelles, L.A., 495 Sette, L.D., Gomes, E., Rodrigues, A. 2016. Fungal communities in pressmud composting harbour beneficial and detrimental fungi for human welfare. Microbiology. 162, 7, 1147-1156. http://dx.doi.org/10.1099/mic.0.000306. 
25. Parks, D.H., Tyson, G.W., Hugenholtz, P., Beiko, R.G. 2014. STAMP: statisticalanalysis of taxonomic and functional profiles. Bioinformatics. http://dx.doi.org/10.1093/bioinformatics/btu494. mechanisms and detoxification of dry olive-mill residue by Cyclocybe aegerita, Mycetinis alliaceus and Chondrostereum purpureum. Int. Biodeterior. Biodegrad. 117, 89-96.

27. Ryckeboer, J., Mergaert, J., Vaes, K., Klammer, S., De Clercq, D., Coosemans, J., Insam, H., Swings, J. 2003. A survey of bacteria and fungi occurring during composting and self-heating processes. An. Micro. 53, 4, 349410.

28. Schoch, C. L., Sung, G. H., López-Giráldez, F., Townsend, J. P., Miadlikowska, J., Hofstetter, V., ... \& Gueidan, C. (2009). The Ascomycota tree of life: a phylum-wide phylogeny clarifies the origin and evolution of fundamental reproductive and ecological traits. Systematic biology, 58(2), 224239.

29. Sampedro, I., Aranda, E., Martın, J., Garcı-Garrido, J.M., GarciaRomera, I., Ocampo, J.A. 2004. Saprobic fungi decrease plant toxicity caused by olive mill residues. Appl. Soil Ecol. 26(2), 149-156. 
Coprinellus disseminatus in solid-state fermentation. New Biotechnol. 26(3-4), community and cellulose-degrading genes in the composting process of Chinese medicinal herbal residues. Bioresour. Technol. 241, 374-383. http://dx.doi.org/10.1016/j.biortech.2017.05.116. primers for the DNA-based identification of ascomycetes and basidiomycetes in environmental samples. PLoS One. 7, 7, e40863. http://dx.doi.org/10.1371/journal.pone.0040863. production of commercial organic amendments and fertilisers by composting of two-phase olive mill waste (“'alperujo”). J. Clean. Prod. 26, 48-55. https://doi.org/10.1016/j.jclepro.2011.12.008.

34. Tortosa, G., Alburquerque, J.A., Bedmar, E.J., Ait Baddi, G., Cegarra, J. 2014. Strategies to produce commercial liquid organic fertilisers from "alperujo" composts. J. Clean. Prod. 82, 37-44. https://doi.org/10.1016/j.jclepro.2014.06.083. 2017. Evolution of bacterial diversity during two-phase olive mill waste (“alperujo") composting by $16 \mathrm{~S}$ rRNA gene pyrosequencing. Bioresour. Technol. 224, 101-111. http://dx.doi.org/10.1016/j.biortech.2016.11.098. 
36. Tuomela, M., Vikman, M., Hatakka, A., Itävaara, M. 2000.

Biodegradation of lignin in a compost environment: a review. Bioresour. Penicillium expansum on the microbial community and maturity of compost. Bioresour. Technol. 102, 24, 11189-11193.

\section{http://dx.doi.org1/0.1016/j.biortech.2011.07.044}

38. Wang, K., Yin, X., Mao, H., Chu, C., Tian, Y. 2018a. Changes in structure and function of fungal community in cow manure composting.

Bioresour. Technol. 255, 123-130.

http://dx.doi.org/10.1016/j.biortech.2018.01.064.

39. Wang, K., Mao, H., Li, X. 2018b. Functional characteristics and influence factors of microbial community in sewage sludge composting with inorganic bulking agent. Bioresour. Technol. 249, 527-535. https://doi.org/10.1016/j.biortech.2017.10.034. 


\section{$564 \quad$ Figure captions}

565 Figure 1. Evolution of relative abundance of phyla during mesophilic, thermophilic and

566 maturation phases, respectively. For each taxa, different letter indicates statistical

567 difference $(p<0.05)$.

568

569 Figure 2. Evolution of the main order identified during mesophilic, thermophilic and

570 maturation phases, respectively. For each taxa, different letter indicates statistical

571 difference $(p<0.05)$.

572

573 Figure 3. 18S rRNA gene copies from genomic (gDNA) and retrotranscripted (cDNA)

574 DNA during mesophilic, thermophilic and maturation phases, respectively. For each

575 sample, different letter indicates statistical difference $(p<0.05)$.

576

577 Figure 4. Order taxa heatmap (left) and principal component analysis (PCA, right)

578 during mesophilic (blue), thermophilic (orange) and maturation (green) phases,

579 respectively. 
581

582 Table 1. Taxa $(\mathrm{N})$ and sequences $(\mathrm{S})$ number obtained from Illumina-sequencing data at 583 mesophilic (Meso 1-3), thermophilic (Thermo 1-3) and maturation (Matu 1-3) phases, 584 respectively.

585

586 Table 2. OTUs Richness (R), Singletons, Good's coverage (\%) and diversity indices

587 Shannon-Wiener (H') and Chao-1 from Illumina-sequencing data at mesophilic (Meso

588 1-3), thermophilic (Thermo 1-3) and maturation (Matu 1-3) phases, respectively.

589

590 Table 3. Relative abundance (\%) of the different fungal genera at mesophilic (Meso 1-

591 3), thermophilic (Thermo 1-3) and maturation (Matu 1-3) phases, respectively. Data are 592 shown as the mean value of three replicates \pm standard deviation.

593

594 Table 4. Pearson correlation matrix $(n=18)$ between composting parameters and Order

595 taxa identified during AL composting. Green folders represent parameters with

596 correlation coefficients $>0.70$, respectively. 
Figure 1

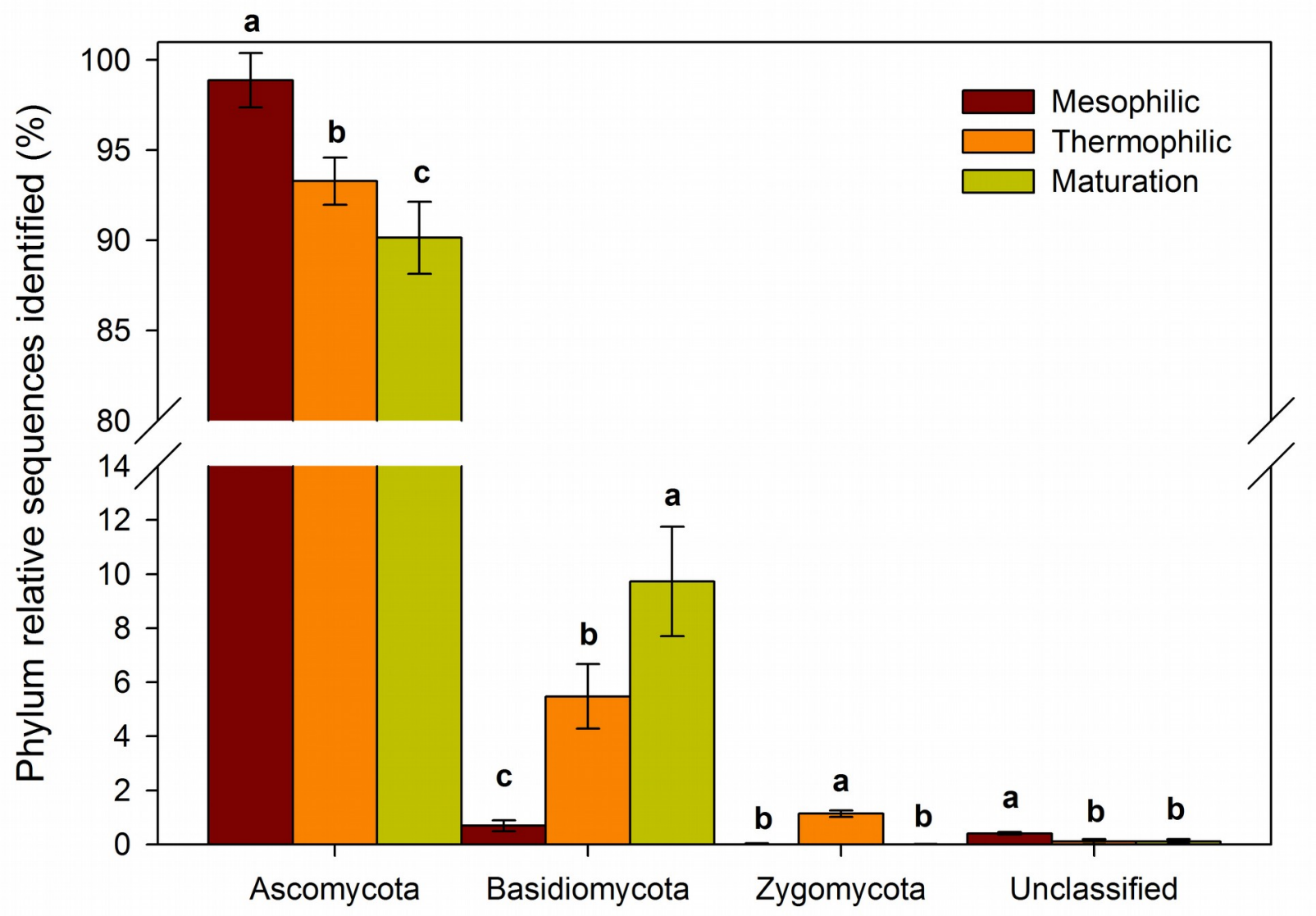


Figure 2

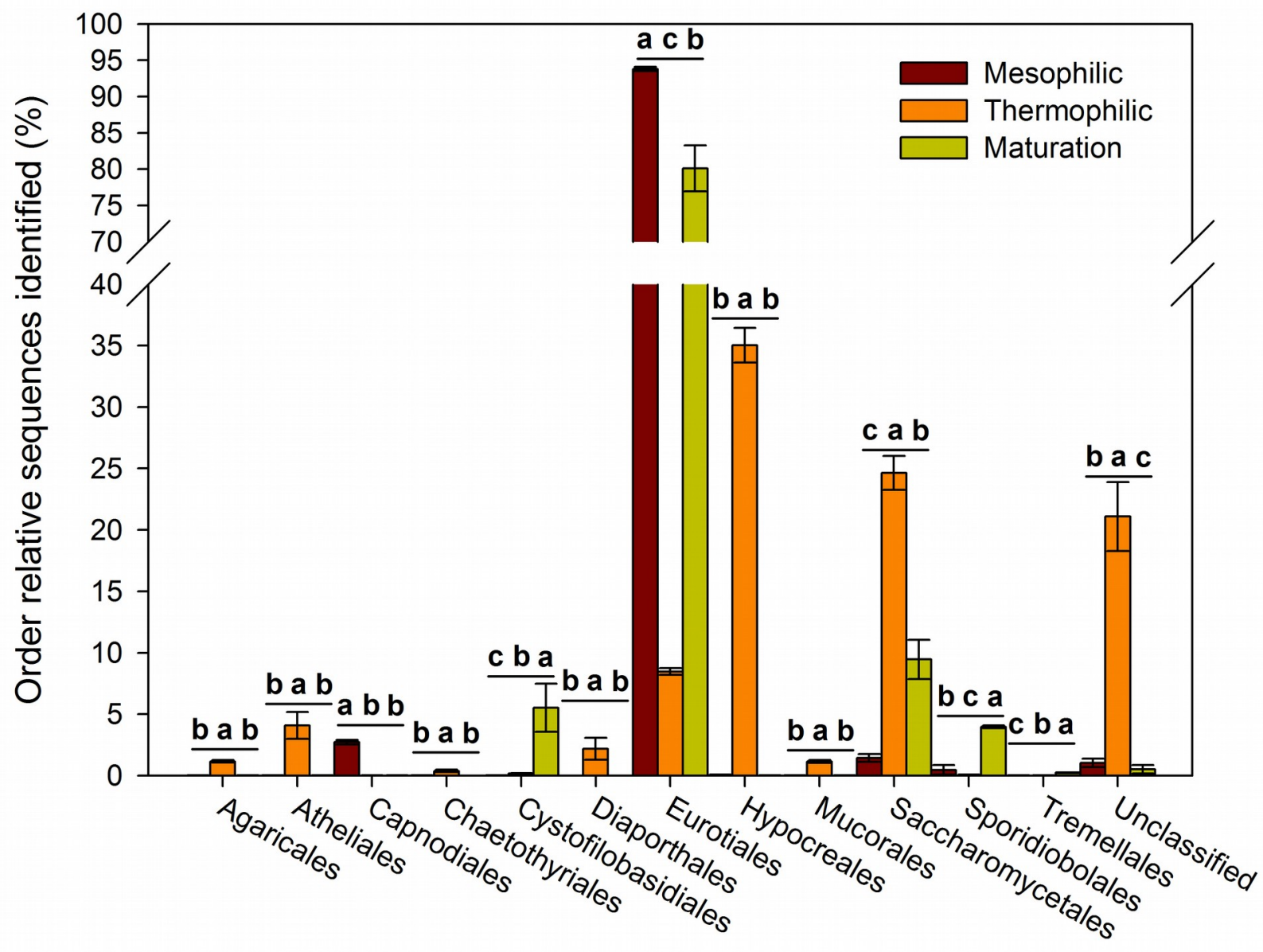


Figure 3

Fungal Total DNA

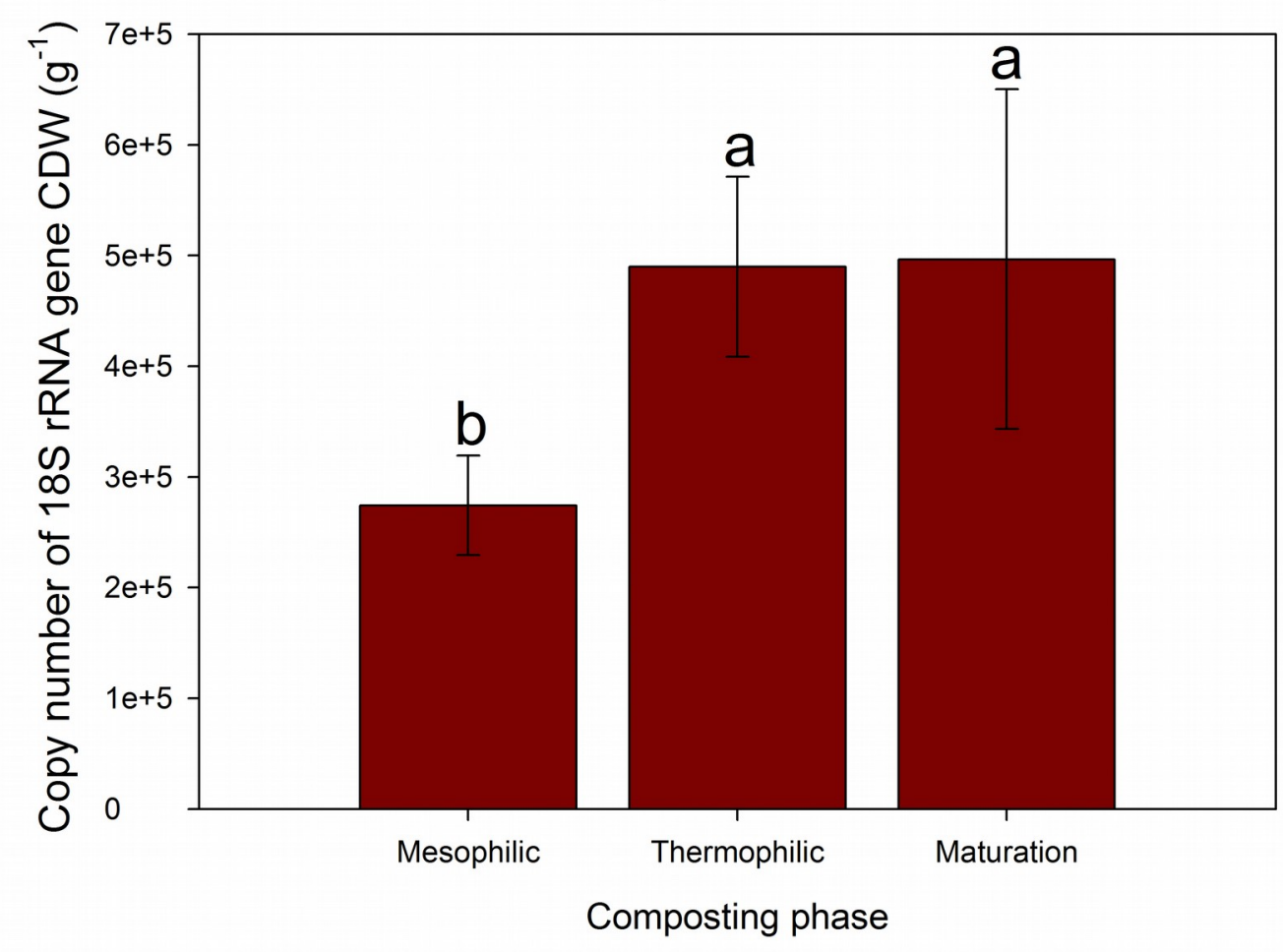

Fungal Retrotranscript DNA (cDNA)

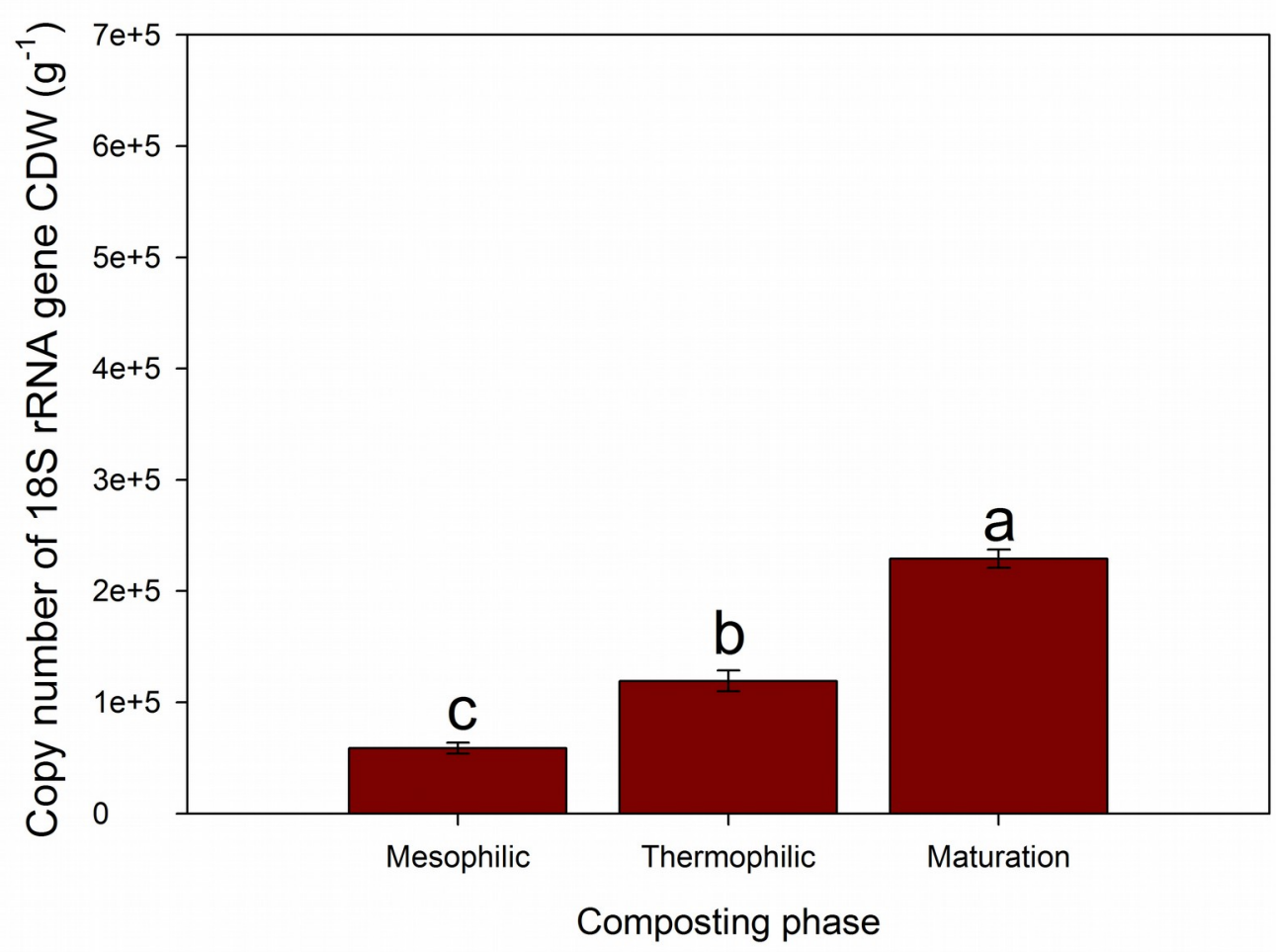


Figure 4

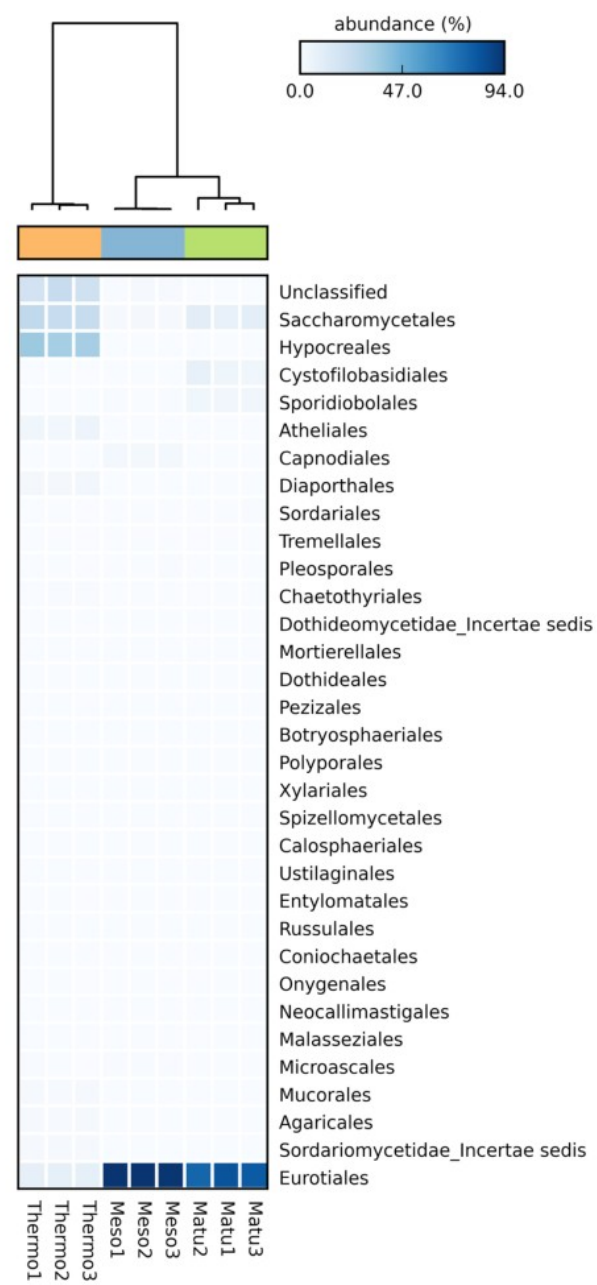

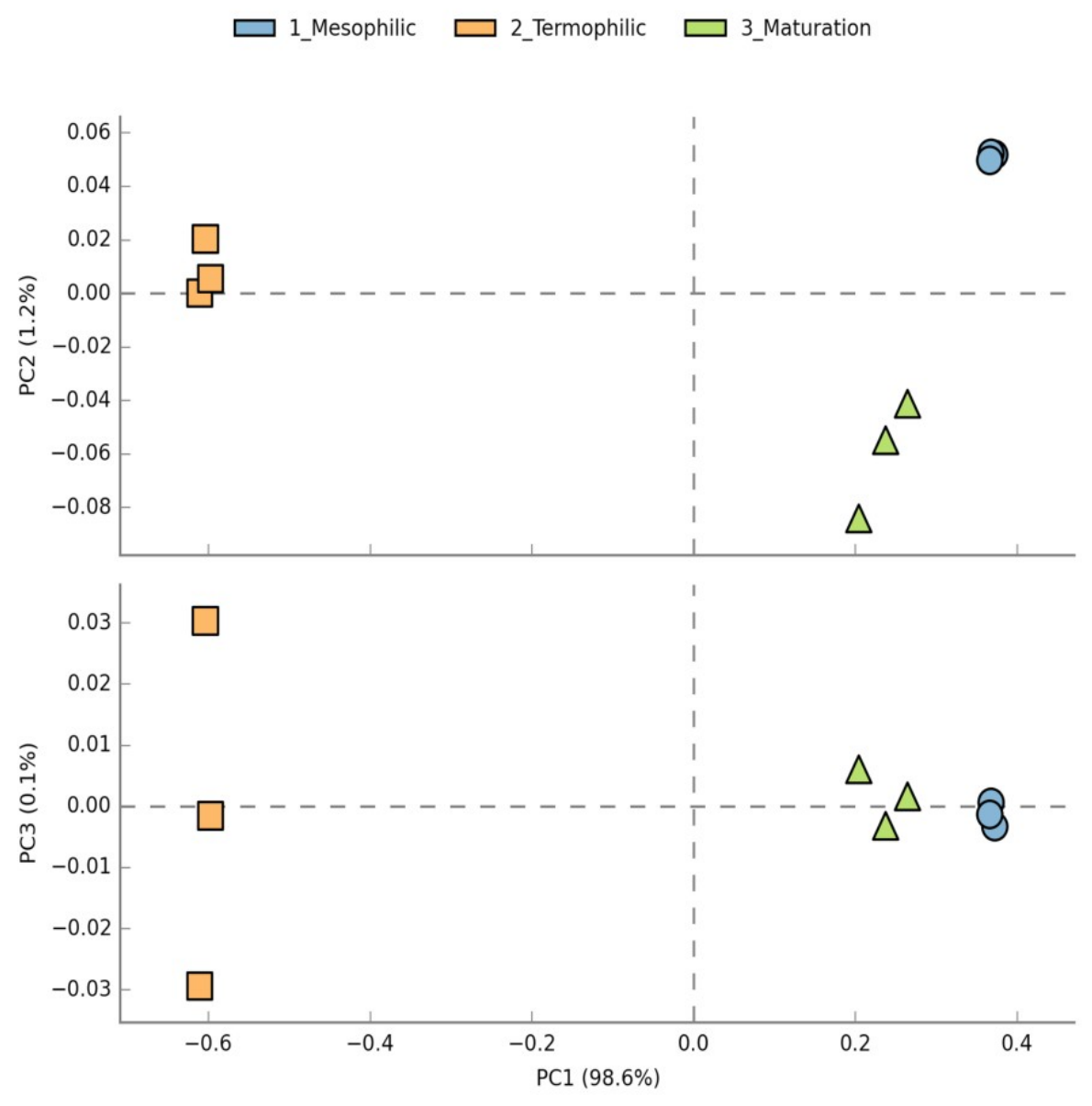


Table 1.

\begin{tabular}{|c|c|c|c|c|c|c|}
\hline \multirow{3}{*}{ AL compost } & \multicolumn{6}{|c|}{ Composting phase libraries } \\
\hline & \multicolumn{2}{|c|}{ Meso1-3 } & \multicolumn{2}{|c|}{ Thermo1-3 } & \multicolumn{2}{|c|}{ Matu1-3 } \\
\hline & $\mathrm{N}$ & $\mathrm{S}$ & $\mathrm{N}$ & $\mathrm{S}$ & $\mathrm{N}$ & $\mathrm{S}$ \\
\hline Phylum & $4 \pm 1$ & $\begin{array}{c}81041 \pm 10299 \\
(99.6 \%)\end{array}$ & $3 \pm 0$ & $\begin{array}{c}77932 \pm 10685 \\
(99.9 \%)\end{array}$ & $4 \pm 1$ & $\begin{array}{c}73179 \pm 25204 \\
(99.9 \%)\end{array}$ \\
\hline Class & $11 \pm 2$ & $\begin{array}{c}80962 \pm 10308 \\
\quad(99.5 \%)\end{array}$ & $9 \pm 0$ & $\begin{array}{c}76069 \pm 11209 \\
(97.5 \%)\end{array}$ & $10 \pm 1$ & $\begin{array}{c}73158 \pm 25193 \\
(99.9 \%)\end{array}$ \\
\hline Order & $19 \pm 5$ & $\begin{array}{c}80723 \pm 10501 \\
(99.2 \%)\end{array}$ & $19 \pm 1$ & $\begin{array}{c}61848 \pm 9732 \\
(79.3 \%)\end{array}$ & $18 \pm 2$ & $\begin{array}{c}73133 \pm 25187 \\
\quad(99.8 \%)\end{array}$ \\
\hline Family & $23 \pm 6$ & $\begin{array}{c}80763 \pm 10303 \\
(99.2 \%)\end{array}$ & $26 \pm 1$ & $\begin{array}{c}61649 \pm 9765 \\
(79.0 \%)\end{array}$ & $23 \pm 1$ & $\begin{array}{c}73128 \pm 25185 \\
(99.8 \%)\end{array}$ \\
\hline Genus & $32 \pm 7$ & $\begin{array}{c}79952 \pm 10640 \\
(98.2 \%)\end{array}$ & $37 \pm 2$ & $\begin{array}{c}60452 \pm 9557 \\
(77.5 \%)\end{array}$ & $34 \pm 3$ & $\begin{array}{c}73012 \pm 25143 \\
(99.7 \%)\end{array}$ \\
\hline $\begin{array}{l}\text { Total sequences } \\
\text { identified }\end{array}$ & \multicolumn{2}{|c|}{$81375 \pm 10311(100 \%)$} & \multicolumn{2}{|c|}{$78016 \pm 10714(100 \%)$} & \multicolumn{2}{|c|}{$73263 \pm 25243(100 \%)$} \\
\hline $\begin{array}{l}\text { Total unclassified } \\
\text { sequences }\end{array}$ & \multicolumn{2}{|c|}{$334 \pm 49(0.4 \%)$} & \multicolumn{2}{|c|}{$83 \pm 34(0.1 \%)$} & \multicolumn{2}{|c|}{$84 \pm 47(0.1 \%)$} \\
\hline
\end{tabular}

Note: Values are expressed as the mean of the sequences from each library and \pm its standard deviation. Numbers in brackets represent the percentage of identified sequences respect to the total identified sequences. 
Table 2.

\begin{tabular}{lccccc}
\hline Composting phase & Richness (OTUs) & Singletons Good's coverage (\%) & $\begin{array}{c}\text { Shannon- } \\
\text { Weiner }\left(\mathrm{H}^{\prime}\right)\end{array}$ & Chao-1 \\
\hline Meso1-3 & $1426 \mathrm{a}$ & $4095 \mathrm{a}$ & $94.9 \mathrm{~b}$ & $2.77 \mathrm{a}$ & $2715 \mathrm{a}$ \\
\hline Thermo1-3 & $2320 \mathrm{~b}$ & $7611 \mathrm{c}$ & $90.2 \mathrm{a}$ & $4.29 \mathrm{c}$ & $3844 \mathrm{~b}$ \\
\hline Matu1-3 & $1437 \mathrm{a}$ & $4346 \mathrm{~b}$ & $93.9 \mathrm{~b}$ & $3.14 \mathrm{~b}$ & $2558 \mathrm{a}$ \\
\hline
\end{tabular}

Note: Different lower-case letter among composting phases indicate statistical differences according to one-way ANOVA with Tukey-Kramer post-hoc test at $p<0.05$. Good's coverage index was calculated as [(1-singletons/total number of sequences) $\mathrm{x} 100]$. 
Table 3.

Relative abundance (\%)

Composting phase libraries

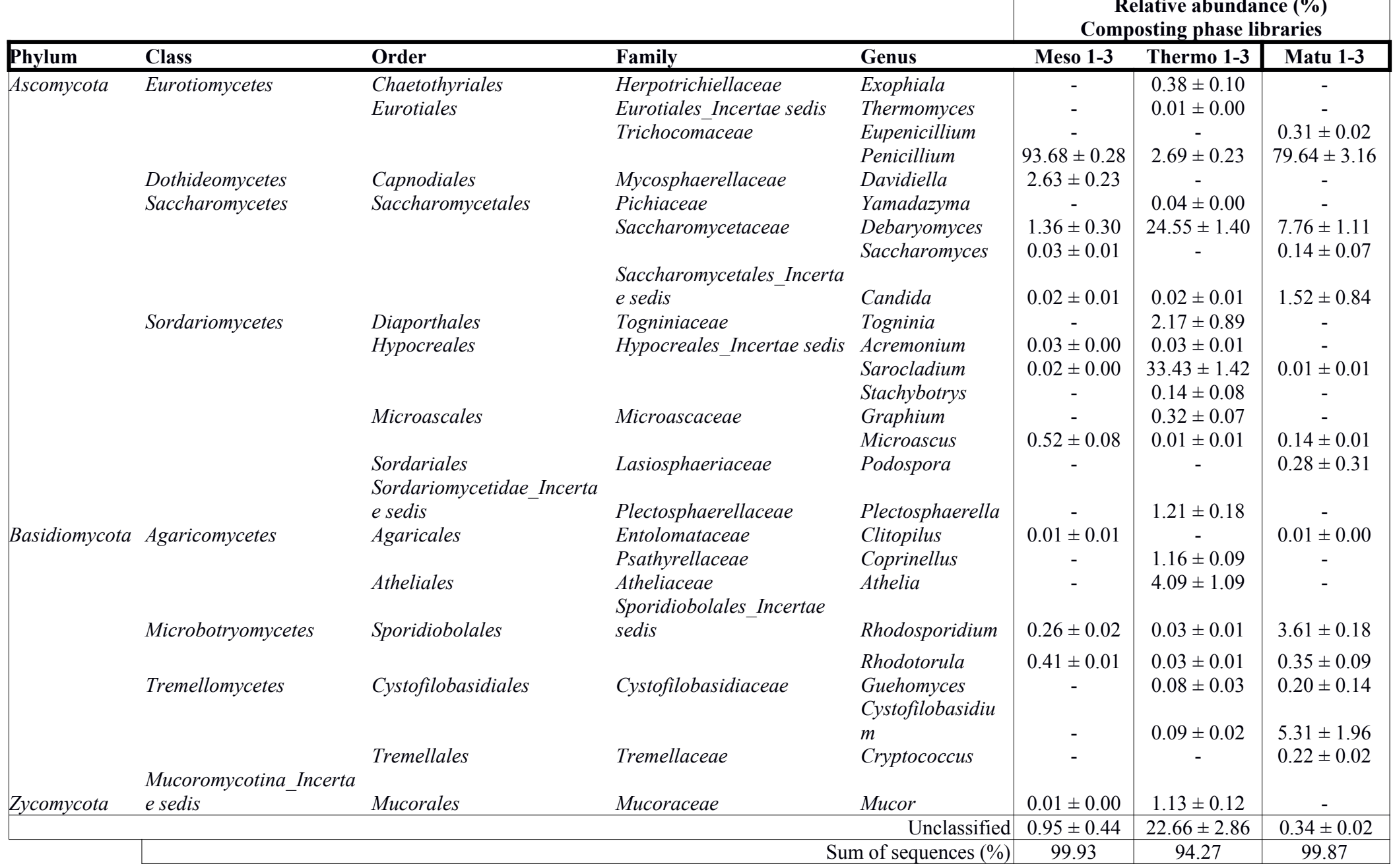




\section{Table 4.}

\begin{tabular}{|c|c|c|c|c|c|c|c|c|c|c|c|c|c|c|c|c|c|c|c|c|c|c|c|}
\hline Phylum & Order & Temp & $\mathrm{pH}$ & EC & $\mathrm{OM}$ & Lig & Cellu & Hemi & $\mathrm{T}_{\mathrm{OC}}$ & $\mathrm{T}_{\mathrm{N}}$ & $\mathrm{CN}$ & Fat & WSC & WSCH & HR & HD & $\mathrm{P}_{\mathrm{AH}}$ & GI & Shanon & Chao1 & Good & gDNA & cDNA \\
\hline \multirow[t]{12}{*}{ Ascomycota } & Capnodiales & $0,21^{*}$ & $\begin{array}{c}- \\
0,79 * *\end{array}$ & $0,56^{* *}$ & $0,88^{* *}$ & $\begin{array}{c}- \\
0,76^{* *}\end{array}$ & $0,43^{* *}$ & $0,92 * *$ & $0,62 * *$ & $\begin{array}{c}- \\
0,21^{* *}\end{array}$ & $0,61^{* *}$ & $0,90 * *$ & $-0,01 *$ & $0,86^{* *}$ & $\begin{array}{c}- \\
0,83^{* *}\end{array}$ & $\begin{array}{c}- \\
0,92 * *\end{array}$ & $\begin{array}{c}- \\
0,90^{* *}\end{array}$ & $\begin{array}{c}- \\
0,68^{* *}\end{array}$ & $-0,68 * *$ & $-0,33 * *$ & $0,66 * *$ & $-0,78^{* *}$ & $-0,37 * *$ \\
\hline & Chaetothyriales & $0,72 * *$ & $-0,10^{*}$ & $0,42^{* *}$ & $-0,04^{*}$ & $-0,15^{*}$ & $0,81^{* *}$ & $-0,15^{*}$ & $0,35^{*}$ & $0,71^{* *}$ & $0,32 *$ & $-0,10 *$ & $0,48 * *$ & $-0,01^{*}$ & $0,15^{*}$ & $0,14^{*}$ & $0,08^{*}$ & $-0,28^{*}$ & $0,94^{* *}$ & $0,87^{* *}$ & $0,95^{* *}$ & $0,32 * *$ & $-0,19 *$ \\
\hline & Diaporthales & $0,70^{* *}$ & $-0,09 *$ & $0,41^{* *}$ & $-0,02 *$ & $-0,15^{*}$ & $0,81^{* *}$ & $-0,15^{*}$ & $0,33^{*}$ & $0,63 * *$ & $0,30 *$ & $-0,08^{*}$ & $0,72 * *$ & $0,03^{*}$ & $0,15^{*}$ & $0,13^{*}$ & $0,07^{*}$ & $-0,27 *$ & $0,91 * *$ & $0,90 * *$ & $\overline{-}^{-}, 88^{* *}$ & $0,23^{*}$ & $-0,22^{*}$ \\
\hline & $\begin{array}{l}\text { Dothideomycetidae_Incertae } \\
\text { sedis }\end{array}$ & $0,56^{*}$ & $-0,06^{*}$ & $0,33^{* *}$ & $-0,01 *$ & $-0,14^{*}$ & $\begin{array}{c}- \\
0,69 * *\end{array}$ & $-0,14^{*}$ & $0,27^{*}$ & $0,41^{* *}$ & $0,23^{*}$ & $-0,07^{*}$ & $0,60^{*}$ & $0,04 *$ & $0,12^{*}$ & $0,10^{*}$ & $0,05^{*}$ & $-0,22 *$ & $0,75^{* *}$ & $0,70 * *$ & $\begin{array}{c}- \\
0,63^{* *}\end{array}$ & $0,21^{*}$ & $-0,19 *$ \\
\hline & Eurotiales & $-0,63 *$ & $-0,04^{*}$ & $-0,30^{*}$ & $0,18^{*}$ & $0,02^{*}$ & $0,82 * *$ & $0,30 *$ & $\begin{array}{c}- \\
0,23 * *\end{array}$ & $\begin{array}{c}- \\
0,64 * *\end{array}$ & $-0,19 *$ & $0,25^{*}$ & $-0,37 *$ & $0,16^{*}$ & $-0,26^{*}$ & $-0,29 *$ & $-0,22^{*}$ & $0,15^{*}$ & $-0,99 * *$ & $-0,83 * *$ & $0,96 * *$ & $-0,48 * *$ & $0,12^{*}$ \\
\hline & Hypocreales & $0,73 * *$ & $-0,10^{*}$ & $0,44^{*}$ & $-0,03^{*}$ & $\begin{array}{c}- \\
0,17 * * \\
\end{array}$ & $0,84^{* *}$ & $-0,16^{*}$ & $0,37 * *$ & $0,69 * *$ & $0,32 *$ & $-0,10 *$ & $0,39 *$ & $-0,01^{*}$ & $0,15^{* *}$ & $0,15^{*}$ & $0,08^{*}$ & $-0,30 *$ & $0,97 * *$ & $0,84^{* *}$ & $\overline{-}-\overline{9} * *$ & $0,38^{* *}$ & $-0,18^{*}$ \\
\hline & Malasseziales & $-0,27 *$ & $-0,23^{*}$ & $-0,08^{*}$ & $0,19 *$ & $\begin{array}{c}- \\
0,15^{* *}\end{array}$ & $0,68^{* *}$ & $0,32 *$ & $-0,04 *$ & $\begin{array}{c}- \\
0,62 * * \\
\end{array}$ & $0,13^{*}$ & $0,23 *$ & $-0,19 *$ & $0,16^{*}$ & $-0,30 *$ & $-0,31 *$ & $\begin{array}{c}- \\
0,27^{* *}\end{array}$ & $-0,04 *$ & $-0,59 * *$ & $-0,25^{*}$ & $0,67 * *$ & $0,01^{*}$ & $-0,49 * *$ \\
\hline & Mortierellales & $0,12^{*}$ & $\begin{array}{r}- \\
0,59 * * \\
\end{array}$ & $0,43^{*}$ & $0,67 * *$ & $0,59 * *$ & $0,38 * *$ & $0,67 * *$ & $0,47 * *$ & $-0,14^{*}$ & $0,46^{*}$ & $0,64 * *$ & NS & $0,61 *$ & $\begin{array}{c}- \\
0,59 * * \\
\end{array}$ & $\begin{array}{c}- \\
0,69 * * \\
\end{array}$ & $\begin{array}{c}- \\
0,68^{* *}\end{array}$ & $-0,51^{*}$ & $-0,51^{* *}$ & $-0,15^{*}$ & $0,51^{* *}$ & $-0,66 * *$ & $-0,31 *$ \\
\hline & Pleosporales & $0,65^{* *}$ & $\begin{array}{r}- \\
0,53^{* *} \\
\end{array}$ & $0,66^{* *}$ & $0,49 *$ & $\begin{array}{c}- \\
0,59 * * \\
\end{array}$ & $0,30^{* *}$ & $0,44^{* *}$ & $0,64 * *$ & $0,48^{* *}$ & $0,62^{* *}$ & $0,45^{* *}$ & $0,22 *$ & $0,47^{*}$ & $-0,27^{*}$ & $\begin{array}{c}- \\
0,42 * * \\
\end{array}$ & $-0,47^{*}$ & $\begin{array}{c}- \\
0,62 * * \\
\end{array}$ & $0,34 * *$ & $0,40^{* *}$ & $0, \overline{4}$ ** & $-0,15^{*}$ & $-0,38 * *$ \\
\hline & Saccharomycetales & $0,46 * *$ & $0,22 *$ & $0,10 * *$ & $-0,37 *$ & $0,17^{*}$ & $\begin{array}{c}- \\
0,75^{* *} \\
\end{array}$ & $0,48^{* * *}$ & $0,03^{*}$ & $0,53 * *$ & $0,02 *$ & $0, \overline{-} 3^{* *}$ & $0,28 *$ & $-0,35^{*}$ & $0,40^{*}$ & $0,47 * *$ & $0,40 *$ & $0,04^{*}$ & $0,99 * *$ & $0,76^{* *}$ & $0,93 * *$ & $0,62^{* *}$ & $-0,04^{*}$ \\
\hline & Sordariales & $\begin{array}{c}- \\
0,64 * * \\
\end{array}$ & $0,52 * *$ & $0,70^{* * *}$ & $-0,62 *$ & $0,60 * *$ & $0,49 * *$ & $\begin{array}{c}- \\
0,50 * *\end{array}$ & $\begin{array}{c}- \\
0,69 * * \\
\end{array}$ & $\begin{array}{r}- \\
0,59 * * \\
\end{array}$ & $\begin{array}{c}- \\
0,51 * * \\
\end{array}$ & $\begin{array}{c}- \\
0,58^{* *}\end{array}$ & $-0,28 *$ & $-0,64 * *$ & $0,42 * *$ & $0,51^{*}$ & $0,55^{*}$ & $0,66 * *$ & $-0,18^{*}$ & $-0,15^{*}$ & $0,29 * *$ & $0,62 * *$ & $-0,08 *$ \\
\hline & $\begin{array}{l}\text { Sordariomycetidae_Incertae } \\
\text { sedis }\end{array}$ & $0,74^{* *}$ & $-0,10^{*}$ & $0,44^{*}$ & $-0,03^{*}$ & $\begin{array}{c}- \\
0,17 * * \\
\end{array}$ & $\begin{array}{c}- \\
0,84^{* *}\end{array}$ & $-0,16^{*}$ & $0,37 * *$ & $0,68^{* *}$ & $0,32 *$ & $-0,09 *$ & $0,53 * *$ & $0,01 *$ & $0,15^{*}$ & $0,14 * *$ & $0,07^{*}$ & $-0,30 *$ & $0,97 * *$ & $0,89 * *$ & $\begin{array}{c}- \\
0,93^{* *}\end{array}$ & $0,32 *$ & $-0,20 *$ \\
\hline \multirow[t]{5}{*}{ Basidiomycota } & Agaricales & $0,73 * *$ & $-0,09 *$ & $0,44^{* *}$ & $-0,03 *$ & $-0,16^{*}$ & $0,85^{* *}$ & $-0,16^{*}$ & $0,37 * *$ & $0,68^{* *}$ & $0,32 * *$ & $-0,10 *$ & $0,47 * *$ & $-0,01^{*}$ & $0,16^{*}$ & $0,15^{*}$ & $0,08^{*}$ & $-0,29 *$ & $0,97 * *$ & $0,87 * *$ & $0,94^{* *}$ & $0,35^{* *}$ & $-0,19 *$ \\
\hline & Atheliales & $0,72 * *$ & $-0,09 *$ & $0,42^{*}$ & $-0,02 *$ & $-0,16^{*}$ & $\begin{array}{c}- \\
0,84^{* *}\end{array}$ & $-0,16^{*}$ & $0,35 * *$ & $0,64^{* *}$ & $0,31^{*}$ & $-0,09 *$ & $0,59 * *$ & $0,02 *$ & $0,15^{*}$ & $0,14^{*}$ & $0,07 *$ & $-0,28^{*}$ & $0,95^{* *}$ & $0,88^{* *}$ & $0,90 * *$ & $0,30^{*}$ & $-0,21^{* *}$ \\
\hline & Cystofilobasidiales & $0,-$ & $0,81^{* *}$ & $0,94 * *$ & $\begin{array}{c}- \\
0,82^{* *}\end{array}$ & $0,88^{* *}$ & $0,45^{* *}$ & $\begin{array}{r}- \\
0,72^{* *}\end{array}$ & $\begin{array}{c}- \\
0,93^{* *}\end{array}$ & $\begin{array}{c}- \\
0,55^{* *}\end{array}$ & $\begin{array}{c}- \\
0,85^{* *}\end{array}$ & $-0,77 *$ & $-0,37 *$ & $-0,81 * *$ & $0,54 * *$ & $0,74 * *$ & $0,78^{* *}$ & $0,92 * *$ & $-0,23 * *$ & $-0,47 * *$ & $0,27 *$ & $0,39 * *$ & $0,51^{* *}$ \\
\hline & Tremellales & $0,94 *$ & $0,91^{* *}$ & $0,99^{* *}$ & $0,84^{* *}$ & $0,94 * *$ & $0,35^{* *}$ & $\begin{array}{c}- \\
0,78^{* *}\end{array}$ & $\begin{array}{c}- \\
0,99 * *\end{array}$ & $-0,40^{*}$ & $\begin{array}{c}- \\
0,96^{* *}\end{array}$ & $-0,80^{*}$ & $-0,37^{*}$ & $-0,84^{* *}$ & $0,72 * *$ & $0,79 * *$ & $0,83^{* *}$ & $0,98^{* *}$ & $-0,27 * *$ & $-0,52 * *$ & $0,26 *$ & $0,35 * *$ & $0,64 * *$ \\
\hline & Sporidiobolales & $\begin{array}{c}- \\
0,97 * * \\
\end{array}$ & $0,84^{* *}$ & $\begin{array}{c}- \\
0,98^{* *} \\
\end{array}$ & $\begin{array}{c}- \\
0,79 * * \\
\end{array}$ & $0,89 * *$ & $0,48^{* *}$ & $\begin{array}{c}- \\
0,71^{* *}\end{array}$ & $\begin{array}{c}- \\
0,97^{* *} \\
\end{array}$ & $\begin{array}{c}- \\
0,52^{* *}\end{array}$ & $\begin{array}{c}- \\
0,92^{* *}\end{array}$ & $\begin{array}{c}- \\
0,75^{* *}\end{array}$ & $-0,42 *$ & $-0,80 * *$ & $0,62 * *$ & $0,72 * *$ & $0,76 * *$ & $0,95^{* *}$ & $-0,36 * *$ & $-0,56 * *$ & $0,37 *$ & $0,32 * *$ & $0,55^{* *}$ \\
\hline Zycomycota & Mucorales & $0,73^{* *}$ & $-0,10^{*}$ & $0,44^{* *}$ & $-0,02 *$ & $\begin{array}{c}- \\
0,17^{* *}\end{array}$ & $\begin{array}{c}- \\
0,84^{* *}\end{array}$ & $-0,16^{*}$ & $0,37 * *$ & $0,67 * *$ & $0,32 *$ & $-0,10 *$ & $0,44 * *$ & NS & $0,15^{*}$ & $0,14 *$ & $0,07^{*}$ & $-0,30 *$ & $0,96 * *$ & $0,85^{* *}$ & $\begin{array}{c}- \\
0,93^{* *}\end{array}$ & $0,36^{* *}$ & $-0,20 *$ \\
\hline
\end{tabular}

